Web Site: https://jutq.utq.edu.iq/index.php/main

Email: journal@jutq.utq.edu.iq

\title{
Experimental Study of the Shear strength of Self \\ Compacting Concrete T-Beams made with Recycled \\ Concrete as Coarse Aggregate \\ https://doi.org/10.32792/utq/utj/vol14/1/4 \\ Ali Kadr Khtar \\ Asst. Prof. Dr. Jamal Abdul Samad Khudhair \\ alikadrkhtar1986@gmail.com \\ College of Engineering, University of Basrah
}

\begin{abstract}
This paper presents the test results of an experimental study on shear strength of reinforced concrete T-beams cast using self- compacting concrete (SCC) with recycled concrete aggregate (RCA) as a partial replacement of coarse aggregate. Twenty seven T-beams were cast and tested, the variables were the shear span to effective depth ratio $(1,2$ and $3)$, the RCA replacement ratio $(0 \%, 50 \%$ and $75 \%)$ and the amount of web reinforcement. The beams were tested under four-point load condition. During the test, the values of the first crack load and the ultimate load were observed as well as the deformation of the beams.

The experimental results indicated that when increasing the RCA replacement ratio to $50 \%$, the first cracking load and the ultimate load reduced by an average of $30 \%$ and $6 \%$ respectively. When the RCA replacement ratio was $75 \%$, the first cracking load and the ultimate load reduced by $31.6 \%$ and $9.4 \%$ respectively. It can be observed that, at the load $500 \mathrm{kN}$, T-beams with the higher replacement ratio of RCA exhibited slightly higher deflection. Also the first cracking load and the ultimate load decreased with the increase of $(\mathrm{a} / \mathrm{d})$ ratio. The presence of web reinforcement causes an increase of about $16 \%$ in cracking load. This increase seems to be independent of a/d ratio and the RCA replacement ratio. The average increase in ultimate loads were $4.4 \%, 18.9 \%$ and $28.4 \%$ for a/d ratio of 1,2 and 3 respectively. The presence of web reinforcement slightly reduced the measured deflection and crack width, and its effect was more for the lower stirrup spacing.
\end{abstract}

Keywords: T-beam, Self-compacting concrete, Shear strength, Recycled concrete. 


\section{University of Thi-Qar Journal Vol.14 No.1 Mar 2019 \\ Web Site: https://jutq.utq.edu.iq/index.php/main \\ Email: journal@jutq.utq.edu.iq}

\section{دراسة تجريبية لمقاومة القص للعتبات على شكل T من الخرسانة ذاتية الرص المصنوعة باستخدام الخرسانة المعادة كركام خشن فئن الفئل}

الخلاصة

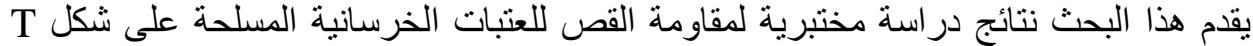

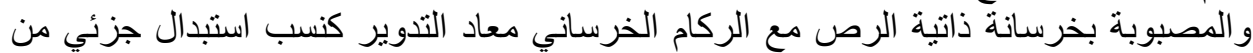

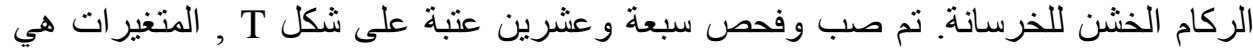

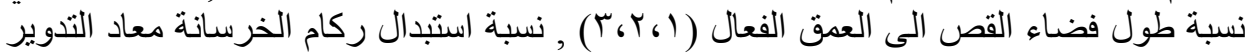

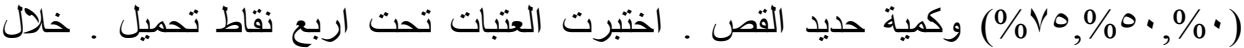
الفحص تم ايجاد قيم حمل التشقق الاولي وحمل الفشل وتم ملاحظة تنشوهات نقات العتبات اثناء

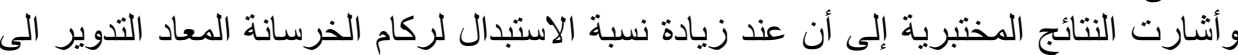

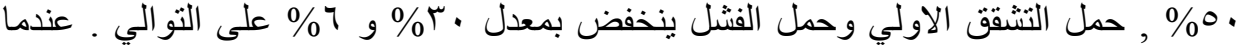

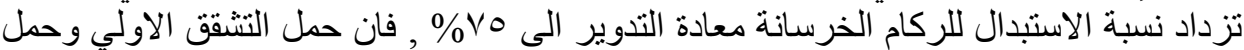

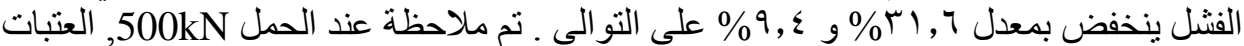

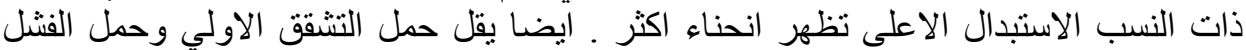

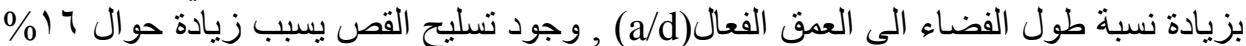

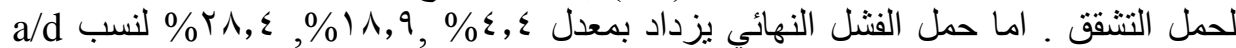

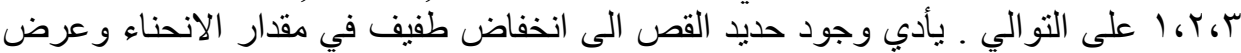

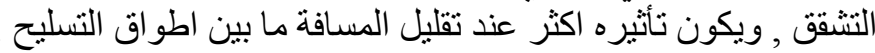

\section{الكلمات المفتاحية: عتبات على شكل T, الخرسانة ذاتية الرص, مقاومة القص, الركام}

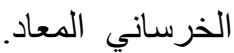

\section{Introduction}

The importance of establishing the suitability of recycled aggregates has increased in recent years against the backdrop of a growing emphasis on sustainable building practices. The rate of building demolition is constantly increasing, making it essential to effectively reuse demolition waste to conserve nonrenewable natural resources. At present a large portion of potentially useful construction and demolition waste is disposed of in landfill sites, creating environmental problems due to scarcity of such sites, unplanned disposal, and environmental cost of transporting demolition waste. The use of coarse recycled concrete aggregates (RCA) as a replacement for natural coarse aggregates in 


\section{University of Thi-Qar Journal Vol.14 No.1 Mar 2019 \\ Web Site: https://jutq.utq.edu.iq/index.php/main \\ Email: journal@jutq.utq.edu.iq}

concrete offers a sustainable solution to these problems. However, the use of RCA may potentially reduce concrete quality as coarse RCAs are generally of poorer quality than natural coarse aggregates, with greater water absorption and lower density [1] .

Self-compacting concrete (SCC) is one of the most important innovations in the concrete technology. It arrived as a revolution in the field of concrete technology. Its distribution worldwide is because of its very attractive properties in the fresh state as well as after hardening. It is a highly workable concrete that can flow through densely reinforced or geometrically complex structural elements under its own weight and sufficiently fills voids without segregation or excessive bleeding without the need for vibration to consolidate it [2,3]. Construction and Demolition waste constitutes a major portion of total solid waste production in the world, and most of it is used in landfills. Research by concrete engineers has clearly suggested the possibility of appropriately treating and reusing such waste as aggregate in new concrete. Recycling is the act of processing the used material for use in creating new product. The utilization of waste material as secondary raw material is the solution to the problem of an excess of waste material, not forgetting the parallel trend of improvement of final product quality [4].

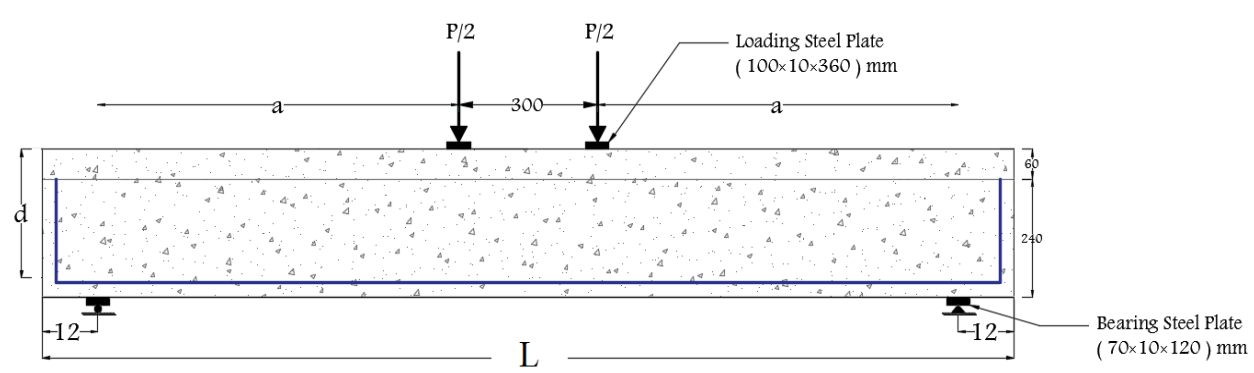

\section{Experimental program}

The experimental program consists of twenty seven SCC T-beams with RCA design to failed in shear with different $(\mathrm{a} / \mathrm{d})$ ratio $(1,2,3)$. Three types of mixes were used, which were differ in the percentage replacement of recycled concrete aggregate $(0 \%, 50 \%, 75 \%)$. For each replacement ratio, three web reinforcement ratios were considered. The full details of the T-beams are presented in Figure(1) and Table (1). 
Figure(1):Details of the tested T-beams

Table (1): Properties of tested T-beams

\begin{tabular}{|c|c|c|c|c|c|}
\hline $\begin{array}{c}\text { T-beam } \\
\text { No. }\end{array}$ & $\begin{array}{c}\text { RCA } \\
\text { content } \\
\mathbf{\%}\end{array}$ & $\mathbf{a / d}$ & $\begin{array}{c}\text { Total } \\
\text { length } \\
(\mathbf{m})\end{array}$ & $\begin{array}{c}\text { Tensile } \\
\text { reinforcement }\end{array}$ & $\begin{array}{c}\text { Web } \\
\text { Reinforcement }\end{array}$ \\
\hline R0S0 & 0 & 1 & 1.06 & $4 \Phi 16$ & None \\
\hline R0S10 & 0 & 1 & 1.06 & $4 \Phi 16$ & $\Phi 6 @ 100 \mathrm{~mm}$ \\
\hline R0S5 & 0 & 1 & 1.06 & $4 \Phi 16$ & $\Phi 6 @ 50 \mathrm{~mm}$ \\
\hline R50S0 & 50 & 1 & 1.06 & $4 \Phi 16$ & None \\
\hline R50S10 & 50 & 1 & 1.06 & $4 \Phi 16$ & $\Phi 6 @ 100 \mathrm{~mm}$ \\
\hline R50S5 & 50 & 1 & 1.06 & $4 \Phi 16$ & $\Phi 6 @ 50 \mathrm{~mm}$ \\
\hline R75S0 & 75 & 1 & 1.06 & $4 \Phi 16$ & None \\
\hline R75S10 & 75 & 1 & 1.06 & $4 \Phi 16$ & $\Phi 6 @ 100 \mathrm{~mm}$ \\
\hline R75S5 & 75 & 1 & 1.06 & $4 \Phi 16$ & $\Phi 6 @ 50 \mathrm{~mm}$ \\
\hline R0S0 & 0 & 2 & 2.58 & $4 \Phi 16$ & None \\
\hline R0S10 & 0 & 2 & 2.58 & $4 \Phi 16$ & $\Phi 6 @ 100 \mathrm{~mm}$ \\
\hline R0S5 & 0 & 2 & 2.58 & $4 \Phi 16$ & $\Phi 6 @ 50 \mathrm{~mm}$ \\
\hline R50S0 & 50 & 2 & 2.58 & $4 \Phi 16$ & None \\
\hline R50S10 & 50 & 2 & 2.58 & $4 \Phi 16$ & Ф6@100mm \\
\hline
\end{tabular}

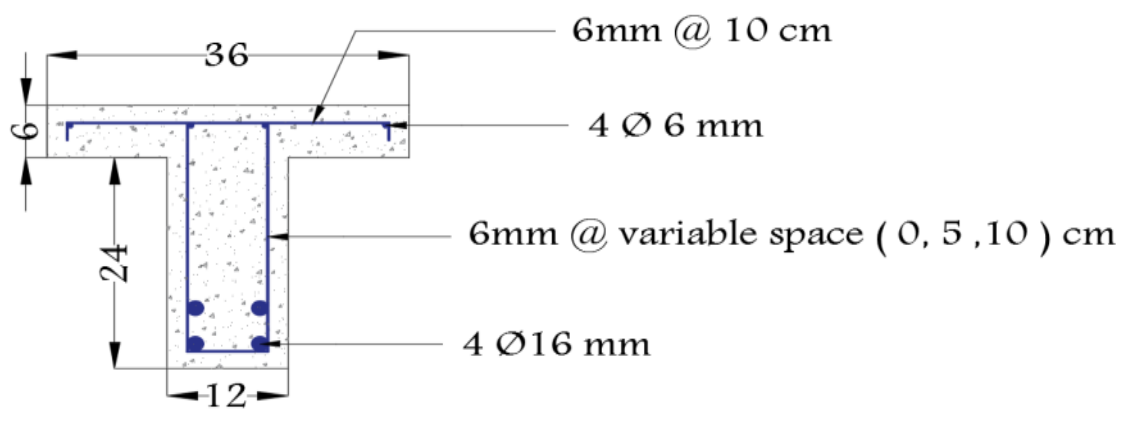


University of Thi-Qar Journal Vol.14 No.1 Mar 2019

Web Site: https://jutq.utq.edu.iq/index.php/main

Email: journal@jutq.utq.edu.iq

\begin{tabular}{|c|c|c|c|c|c||}
\hline R50S5 & 50 & 2 & 2.58 & $4 \Phi 16$ & $\Phi 6 @ 50 \mathrm{~mm}$ \\
\hline R75S0 & 75 & 2 & 2.58 & $4 \Phi 16$ & None \\
\hline R75S10 & 75 & 2 & 2.58 & $4 \Phi 16$ & $\Phi 6 @ 100 \mathrm{~mm}$ \\
\hline R75S5 & 75 & 2 & 2.58 & $4 \Phi 16$ & $\Phi 6 @ 50 \mathrm{~mm}$ \\
\hline R0S0 & 0 & 3 & 2.10 & $4 \Phi 16$ & None \\
\hline R0S10 & 0 & 3 & 2.10 & $4 \Phi 16$ & $\Phi 6 @ 100 \mathrm{~mm}$ \\
\hline R0S5 & 0 & 3 & 2.10 & $4 \Phi 16$ & $\Phi 6 @ 50 \mathrm{~mm}$ \\
\hline R50S0 & 50 & 3 & 2.10 & $4 \Phi 16$ & None \\
\hline R50S10 & 50 & 3 & 2.10 & $4 \Phi 16$ & $\Phi 6 @ 100 \mathrm{~mm}$ \\
\hline R50S5 & 50 & 3 & 2.10 & $4 \Phi 16$ & $\Phi 6 @ 50 \mathrm{~mm}$ \\
\hline R75S0 & 75 & 3 & 2.10 & $4 \Phi 16$ & None \\
\hline R75S10 & 75 & 3 & 2.10 & $4 \Phi 16$ & $\Phi 6 @ 100 \mathrm{~mm}$ \\
\hline R75S5 & 75 & 3 & 2.10 & $4 \Phi 16$ & $\Phi 6 @ 50 \mathrm{~mm}$ \\
\hline
\end{tabular}

\section{Ү, 1. Materials:}

The properties of the materials that used in the preparation of the tested reinforced SCC T-beams with RCA are described below.

\section{r, 1.1 Cement:}

Conventional Portland cement made by Mabrouka cement company was utilized in this study. This cement comply with the Iraqi specifications number (5/1984) [5].

\subsubsection{Water:}

Potable water was utilized for both making and curing the samples of concrete.

\subsubsection{Fine Aggregate}

Normal sand from Al-Zubair, region in Basrah city was utilized. Before using it, the sieve analysis is performed at Material Laboratory in Engineering College of Al-Basra University for ensuring its validity for mixing. The fine aggregate was in region 2 of Iraqi specification number (5 / 1984) [5]. 
Web Site: https://jutq.utq.edu.iq/index.php/main

Email: journal@jutq.utq.edu.iq

\subsubsection{Coarse Aggregate A-Gravel :}

Crushed gravel from Al-Zubair, region in Basrah city with maximum size of $20 \mathrm{~mm}$ was utilized. Before using it, the sieve analysis is performed at Material Laboratory in Engineering College of Al-Basra University for ensuring its validity for mixing The results demonstrate that, the coarse aggregate grading is within the requirements of Iraqi specification No. 45/ 1984 [5].

\section{B-Recycled Concrete Aggregate :}

Recycled concrete aggregate which was utilized in this study was obtained from the destruction of concrete cubes which have been taken to the laboratory for testing. The results demonstrate that, the RCA grading is within the requirements of Iraqi specification No. 45/1984 [5]. The maximum size, of this aggregate was $20 \mathrm{~mm}$.

\subsubsection{Superplasticizer:}

A high performance concrete, superplasticizer ( High Range Water Reduction Agent HRWRA) based on polycarboxylic technology, which is well-known commercially as Glenium 51, is utilized in these tests. Glenium 51 has been principally manufactured for applications in the precast and premixed concrete industries where the highest performance and durability are required. Glenium 51 is free of chlorides and complies with ASTMC494 type a [6].

\subsubsection{Steel Reinforcement}

Steel reinforcing deformed bars of 6 and $16 \mathrm{~mm}$ diameter were used for the longitudinal reinforcement and stirrups. Three tensile specimens of each size of bars were tested. Test results indicated that the bars conformed to the ASTM A615/A615M-04b[7]. The properties of reinforcing bars are presented in Table (2).

Table (2) Properties of reinforcing bars

\begin{tabular}{|c|c|c|c|}
\hline \multirow{2}{*}{$\begin{array}{c}\text { Bar size } \\
(\mathbf{m m})\end{array}$} & \multicolumn{3}{|c|}{ Test results } \\
\cline { 2 - 4 } & $\begin{array}{c}\text { Yield } \\
\text { stress } \\
\left(\mathbf{N} / \mathbf{m m}^{\mathbf{2}}\right)\end{array}$ & $\begin{array}{c}\text { Ultimate Strength } \\
\left(\mathbf{N} / \mathbf{m m}^{2}\right)\end{array}$ & $\begin{array}{c}\text { Elongation } \\
(\%)\end{array}$ \\
\hline 6 & 442 & 656 & 11 \\
\hline 16 & 530 & 677 & 12 \\
\hline
\end{tabular}




\section{University of Thi-Qar Journal Vol.14 No.1 Mar 2019 \\ Web Site: https://jutq.utq.edu.iq/index.php/main \\ Email: journal@jutq.utq.edu.iq}

\subsubsection{Limestone Powder (LSP):}

This material is locally named as Al-Gubra, which has been brought from local market and used to increase the amount of powder (cement + filler). The specific gravity of the (LSP) was 2.4

\subsection{Proportioning of Concrete Mixture}

Concrete is mixed in drum laboratory mixer, with a capacity of $0.1 \mathrm{~m}^{3}$ the mixer was cleaned and moistened before use. Based on Jin's work [8], a fixed mixing procedure was adopted and carried out throughout this research for mixing concrete to achieve maximum super plasticizer efficiency and full dispersion of the powder. The mixing method may be summarized as:

1- Powder (limestone powder and cement) and aggregates (fine and coarse) were blended for one minute.

2 - The first part $80 \%$ of blending water was added gradually and blended for another 1 minute.

3 - The second part $20 \%$ of blending water with superplasticizer dissolved in it was added gradually whereas blending for another one minute.

4- Blending was continuous for additional 3 minutes.

5- The blend was allowed to break for 3.5 minutes.

6 . The blend was remixed for thirty seconds and discharged for casting. From these guidelines and after many trials, one concrete mix has been selected which satisfy the conditions of self-compacting concrete. Table (3) shows the amount of used mix materials.

Table (3) Concrete mix materials

\begin{tabular}{|c|c|}
\hline Material & Content \\
\hline Cement $\mathrm{kg} / \mathrm{m}^{3}$ & 414 \\
\hline Limestone Powder $\mathrm{kg} / \mathrm{m}^{3}$ & 178 \\
\hline Coarse Aggregate $\mathrm{kg} / \mathrm{m}^{3}$ & 778 \\
\hline Fine Aggregate $\mathrm{kg} / \mathrm{m}^{3}$ & 826 \\
\hline Water $\mathrm{kg} / \mathrm{m}^{3}$ & 183 \\
\hline $\mathrm{SP} \mathrm{kg} / \mathrm{m}^{3}$ & 4 \\
\hline
\end{tabular}


University of Thi-Qar Journal Vol.14 No.1 Mar 2019

Web Site: https://jutq.utq.edu.iq/index.php/main

Email: journal@jutq.utq.edu.iq 
Email: journal@jutq.utq.edu.iq

\subsection{Fresh Concrete Tests}

In fresh state SCC is required to have three characteristics; filling ability, passing ability and segregation resistance. Therefore several test methods are implemented in this study in order to ensure that SCC mixes meet these requirements as shown in Table (4).

Table (4): Properties of fresh SCC

\begin{tabular}{|c|c|c|c|c|c|c|c|c|c|c|c|c|}
\hline \multirow{2}{*}{$\begin{array}{c}\text { RC } \\
\text { A } \\
(\%)\end{array}$} & \multirow{2}{*}{$\begin{array}{c}\text { Slum } \\
\mathbf{p} \\
\text { flow } \\
(\mathbf{m m})\end{array}$} & \multicolumn{2}{|c|}{$\begin{array}{l}\text { EFNARC } \\
\text { Guideline }\end{array}$} & \multirow{2}{*}{$\begin{array}{c}\mathbf{T} \\
\mathbf{5 0 0} \\
\text { (sec) }\end{array}$} & \multicolumn{2}{|c|}{$\begin{array}{l}\text { EFNARC } \\
\text { Guideline }\end{array}$} & \multirow{2}{*}{$\begin{array}{c}V- \\
\text { funne } \\
I \\
\text { (sec) }\end{array}$} & \multicolumn{2}{|c|}{$\begin{array}{l}\text { EFNARC } \\
\text { Guideline }\end{array}$} & \multirow{2}{*}{$\begin{array}{l}\text { L- } \\
\text { Box }\end{array}$} & \multicolumn{2}{|c|}{$\begin{array}{l}\text { EFNARC } \\
\text { Guideline }\end{array}$} \\
\hline & & Min. & Max. & & $\begin{array}{c}\text { Mi } \\
\text { n. }\end{array}$ & $\begin{array}{c}\text { Ma } \\
\text { x. }\end{array}$ & & Min. & Max. & & Min. & $\begin{array}{c}\text { Ma } \\
\text { X. }\end{array}$ \\
\hline 0 & 700 & 650 & 800 & 2.66 & 2 & 5 & 8.27 & 8 & 12 & 0.94 & 0.8 & 1.00 \\
\hline 50 & 660 & 650 & 800 & 2.72 & 2 & 5 & 8.56 & 8 & 12 & 0.93 & 0.8 & 1.00 \\
\hline 75 & 610 & 650 & 800 & 3.02 & 2 & 5 & 9.41 & 8 & 12 & 0.89 & 0.8 & 1.00 \\
\hline
\end{tabular}

\subsection{Mechanical Properties of Hardened SCC}

To evaluate the mechanical properties of all types of concrete used in this work, control specimens are cast from the same mixes used for the SCC T-beams. Three mechanical properties are evaluated here: compressive strength of cubes (fcu) ,splitting tensile strength ( $\mathrm{ft}$ ), and modulus of elasticity (Ec). Three specimens were used for each mixture of any property and the average value of the three results are hence, the results are presented in Table(5).

Table(5): Properties of hardened SCC.

\begin{tabular}{|c|c|c|c|c|}
\hline Mix No. & $\begin{array}{c}\text { RCA } \\
\text { Replacement } \\
\text { Ratio }\end{array}$ & $\begin{array}{c}\mathrm{f}_{\mathrm{cu}} \\
(\mathrm{MPa})\end{array}$ & $\mathrm{f}_{\mathrm{t}}(\mathrm{MPa})$ & $\begin{array}{c}\mathrm{Ec} \\
(\mathrm{GPa})\end{array}$ \\
\hline 1 & $0 \%$ & 44.32 & 3.96 & 31.24 \\
\hline 2 & $50 \%$ & 38.63 & 3.43 & 28.94 \\
\hline
\end{tabular}


Web Site: https://jutq.utq.edu.iq/index.php/main

Email: journal@jutq.utq.edu.iq

\begin{tabular}{|l|l|l|l|l|}
\hline 3 & $75 \%$ & 32.11 & 3.12 & 25.67 \\
\hline
\end{tabular}

\section{Results and Discussion}

\subsection{General Behavior and Crack Patterns}

Generally all the tested beams showed similar behaviour and crack propagation during load application. The first diagonal crack suddenly developed at mid-depth of one of the shear spans. As the load increased, the diagonal crack became wider and extended towards the load and support points. With further increase in the applied load more inclined cracks were developed and propagated in both shear spans. In most of the beams the shear cracks were accompanied by the formation of fine flexure cracks at bottom of mid-span. In some beams and near the failure load, the inclined cracks extended through the flange.

T-beams with a/d (1 and 2) failed due to shear compression and T-beams with $\mathrm{a} / \mathrm{d}=3$ failed due to shear diagonal tension as shown in Figure (2). First crack and ultimate loads are shown in Tables (6,7 and 8). 
University of Thi-Qar Journal Vol.14 No.1 Mar 2019

Web Site: https://jutq.utq.edu.iq/index.php/main

Email: journal@jutq.utq.edu.iq

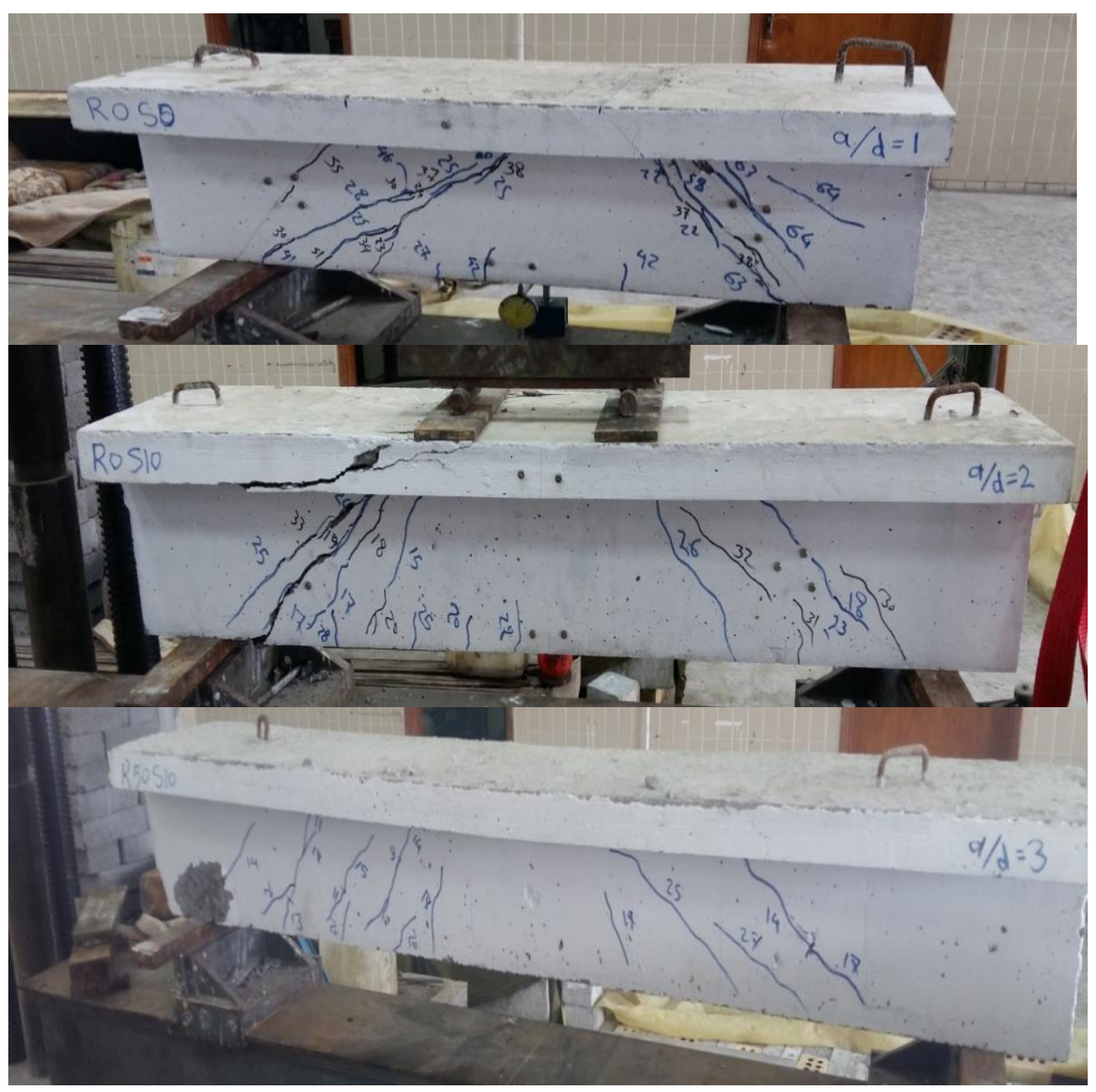

Figure (2): crack pattern for T-beams. 
University of Thi-Qar Journal Vol.14 No.1 Mar 2019

Web Site: https://jutq.utq.edu.iq/index.php/main

Email: journal@jutq.utq.edu.iq

Table(6): First crack and ultimate loads of SCC T-beams (a/d=1).

\begin{tabular}{|c|c|c|c|c|c|}
\hline Specimens & $\begin{array}{r}\text { RCA } \\
(\%)\end{array}$ & $\begin{array}{c}\text { Stirrups } \\
\text { spacing } \\
(\mathrm{mm})\end{array}$ & $\begin{array}{c}\text { Cracking } \\
\text { load } \\
\text { Pcr, }_{\text {ckN })}\end{array}$ & $\begin{array}{c}\text { Ultimate } \\
\text { load } P_{u},(k N)\end{array}$ & $\begin{array}{c}\text { Pcr/Pu } \\
\%\end{array}$ \\
\hline R0S0 & 0 & None & 220 & 640 & 34.0 \\
\hline R0S10 & 0 & 100 & 230 & 640 & 35.9 \\
\hline R0S5 & 0 & 50 & 210 & 650 & 32.3 \\
\hline R50S0 & 50 & None & 140 & 620 & 22.5 \\
\hline R50S10 & 50 & 100 & 150 & 620 & 24.2 \\
\hline R50S5 & 50 & 50 & 170 & 650 & 26.1 \\
\hline R75S0 & 75 & None & 120 & 580 & 20.6 \\
\hline R75S10 & 75 & 100 & 140 & 600 & 23.3 \\
\hline R75S5 & 75 & 50 & 150 & 620 & 24.2 \\
\hline
\end{tabular}


University of Thi-Qar Journal Vol.14 No.1 Mar 2019

Web Site: https://jutq.utq.edu.iq/index.php/main

Email: journal@jutq.utq.edu.iq

Table (7): First crack and ultimate loads of SCC T-beams (a/d=2).

\begin{tabular}{|c|c|c|c|c|c|}
\hline Specimens & $\begin{array}{c}\text { RCA } \\
(\%)\end{array}$ & $\begin{array}{c}\text { Stirrups } \\
\text { spacing } \\
(\mathbf{m m})\end{array}$ & $\begin{array}{c}\text { Cracking } \\
\text { load } \\
\text { Pcr, }(k N)\end{array}$ & $\begin{array}{c}\text { Ultimate } \\
\text { load } \\
\mathbf{P}_{\mathrm{u},(\mathrm{kN})}\end{array}$ & $\begin{array}{c}\text { Pcr/Pu } \\
\%\end{array}$ \\
\hline ROS0 & 0 & None & 140 & 450 & 31.1 \\
\hline R0S10 & $\mathbf{0}$ & 100 & 130 & 490 & 28.8 \\
\hline R0S5 & $\mathbf{0}$ & 50 & 140 & 560 & 25.0 \\
\hline R50S0 & 50 & None & 120 & 480 & 25.0 \\
\hline R50S10 & 50 & 100 & 140 & 480 & 24.2 \\
\hline R50S5 & 50 & 50 & 160 & 550 & 29.1 \\
\hline R75S0 & 75 & None & 100 & 440 & 22.7 \\
\hline R75S10 & 75 & 100 & 110 & 480 & 22.9 \\
\hline R75S5 & 75 & 50 & 120 & 520 & 23.0 \\
\hline
\end{tabular}


University of Thi-Qar Journal Vol.14 No.1 Mar 2019

Web Site: https://jutq.utq.edu.iq/index.php/main

Email: journal@jutq.utq.edu.iq

Table (8): First crack and ultimate loads of SCC T-beams $(\mathrm{a} / \mathrm{d}=3)$.

\begin{tabular}{|c|c|c|c|c|c|}
\hline Specimens & $\begin{array}{r}\text { RCA } \\
(\%)\end{array}$ & $\begin{array}{c}\text { Stirrups } \\
\text { spacing } \\
(\mathrm{mm})\end{array}$ & $\begin{array}{c}\text { Cracking } \\
\text { load } \\
\text { Pcr, }(k N)\end{array}$ & $\begin{array}{c}\text { Ultimate } \\
\text { load } \\
\mathbf{P u}_{\mathbf{u}},(\mathrm{kN})\end{array}$ & $\begin{array}{c}\mathrm{Pcr} / \mathrm{Pu} \\
\%\end{array}$ \\
\hline R0S0 & 0 & None & 110 & 340 & 32.3 \\
\hline R0S10 & 0 & 100 & 120 & 340 & 35.3 \\
\hline R0S5 & $\mathbf{0}$ & 50 & 140 & 400 & 35.0 \\
\hline R50S0 & 50 & None & 80 & 270 & 29.6 \\
\hline R50S10 & 50 & 100 & 90 & 330 & 27.2 \\
\hline R50S5 & 50 & 50 & 100 & 340 & 29.4 \\
\hline R75S0 & 75 & None & 70 & 240 & 29.1 \\
\hline
\end{tabular}


Web Site: https://jutq.utq.edu.iq/index.php/main

Email: journal@jutq.utq.edu.iq

\begin{tabular}{|l||c||c||c||c||c|}
\hline \hline R75S10 & 75 & 100 & 80 & 310 & 25.8 \\
\hline \hline R75S5 & 75 & 50 & 80 & 340 & 23.5 \\
\hline
\end{tabular}

\subsection{Effect of using RCA on SCC T-beams}

\subsubsection{First Cracking and Ultimate Load}

The first cracking load and the ultimate load decreased with the increase in the recycle concrete coarse aggregate ratio as shown in Tables $(8,9$ and $10)$.

For beams with a/d ratio of (1) and with variable stirrups (without stirrups, $\Phi 6$ at $100 \mathrm{~mm}$ and at $50 \mathrm{~mm}$ ), when increasing the RCA replacement ratio to $50 \%$, the first cracking load and the ultimate load reduced by average of $30 \%$ and $2 \%$ respectively. When the RCA replacement ratio was $75 \%$, the first cracking load and the ultimate load reduced $37.7 \%$ and $6.7 \%$ respectively.

For beams with a/d ratio of (2) and with variable stirrups (without stirrups, $\Phi 6$ at $100 \mathrm{~mm}$ and at $50 \mathrm{~mm}$ ), when increasing the RCA replacement ratio to $50 \%$, the first cracking load and the ultimate load is slightly affected. When the RCA replacement ratio was $75 \%$, the first cracking load and the ultimate load reduced $19.4 \%$ and $3.8 \%$ respectively. For beams with a/d ratio of (3) and with variable stirrups (without stirrups, $\Phi 6$ at $100 \mathrm{~mm}$ and at $50 \mathrm{~mm}$ ), when increasing the RCA replacement ratio to $50 \%$, the first cracking load and the ultimate load reduced by average $27 \%$ and $12.8 \%$ respectively. When the RCA replacement ratio was $75 \%$, the first cracking load and the ultimate load reduced $37.5 \%$ and $17.7 \%$ respectively. When increase the replacement ratio of RCA it causes reduction in compressive strength, splitting tensile strength and modulus of elasticity and thus causes a decrease in values first cracking loads and the ultimate loads.

\subsubsection{Deflection}




\section{University of Thi-Qar Journal Vol.14 No.1 Mar 2019 \\ Web Site: https://jutq.utq.edu.iq/index.php/main}

Email: journal@jutq.utq.edu.iq

Figures (3) to (5) present a comparison between deflection of SCC T-beams for replacement ratio of RCA $(0 \%, 50 \%, 75 \%)$. It can be observed that, at the load $500 \mathrm{kN}$, T-beams with the higher replacement ratio of RCA exhibited slightly higher deflection. As an example, at the same load level, and for beam with a/d ratio of (1) and without stirrups, beam with $50 \%$ replacement ratio showed (22\%) higher deflection compared to beam without recycle concrete aggregate while this increase in deflection became (34\%) for beam with $75 \%$ replacement ratio. The increase in deflection for T-beams with increasing the replacement ratio of RCA is attributed to the lower modulus of elasticity and compressive strength of RCA compared to NC.

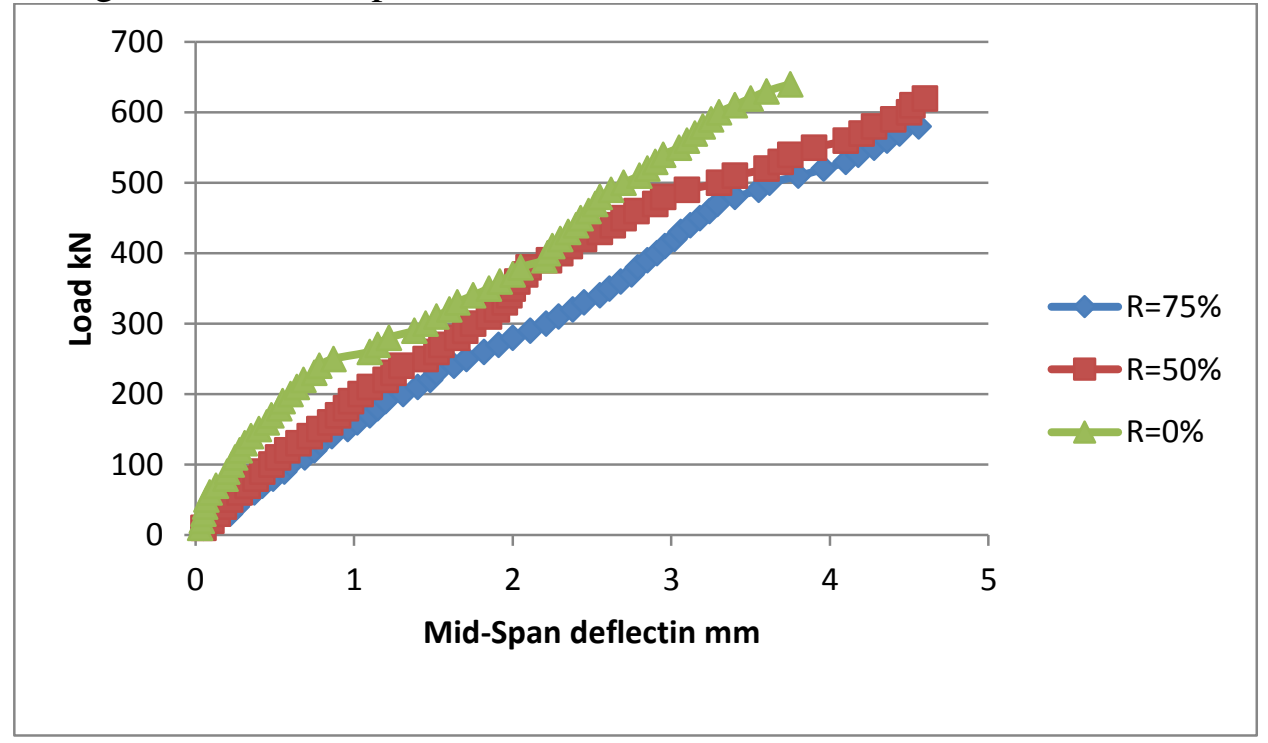

Figure (3): Experimental load versus mid- span deflection curve for T-beams without stirrups and $\mathbf{a} / \mathbf{d}=1$ 
University of Thi-Qar Journal Vol.14 No.1 Mar 2019

Web Site: https://jutq.utq.edu.iq/index.php/main

Email: journal@jutq.utq.edu.iq

00

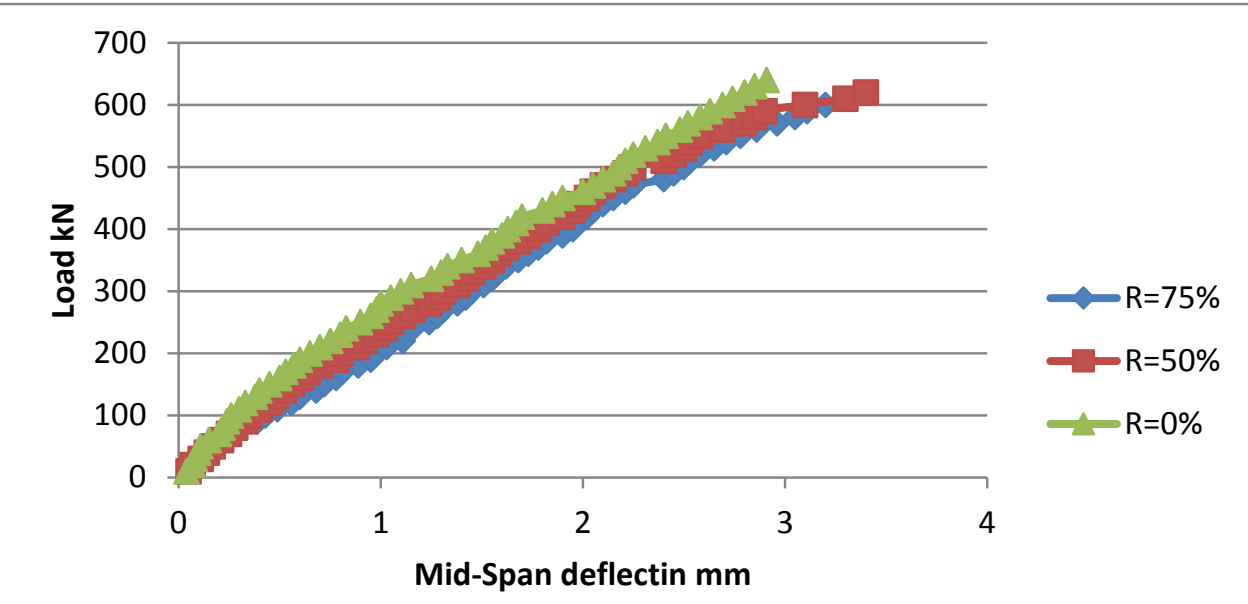

Figure (4): Experimental load versus mid- span deflection curve for $T$-beams with $S=100 \mathrm{~mm}$ stirrups and $\mathrm{a} / \mathrm{d}=1$

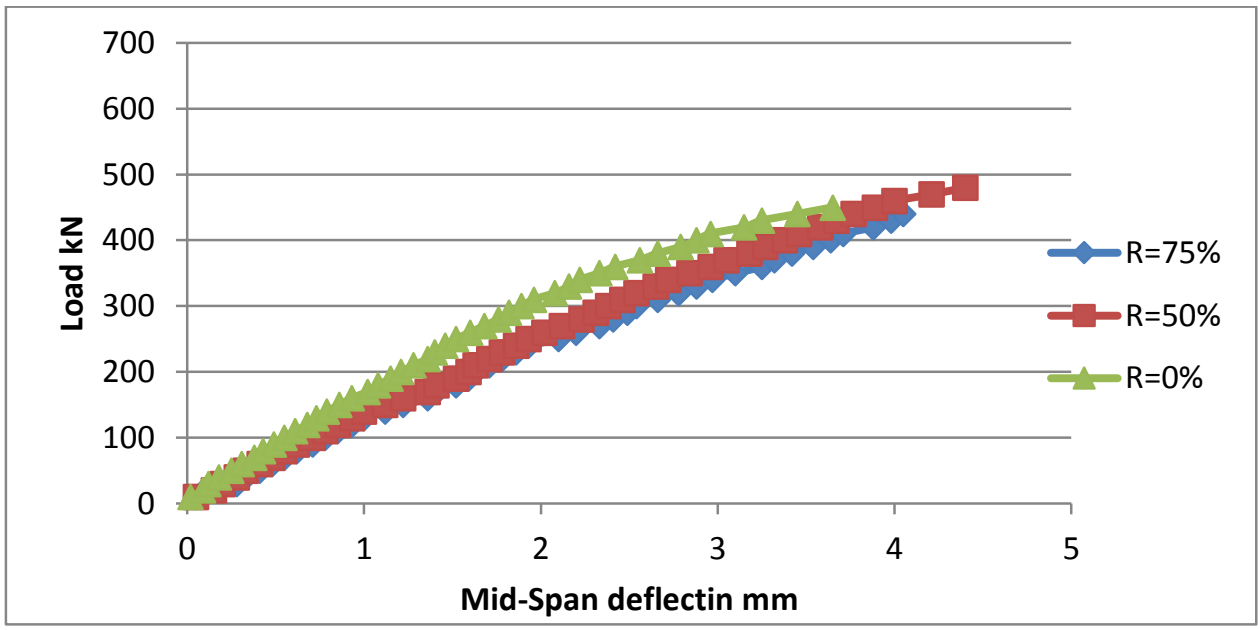

Figure (5): Experimental load versus mid- span deflection curve for T-beams without stirrups and $\mathbf{a} / \mathbf{d}=2$

\subsubsection{Inclined Crack Width}




\section{University of Thi-Qar Journal Vol.14 No.1 Mar 2019 \\ Web Site: https://jutq.utq.edu.iq/index.php/main \\ Email: journal@jutq.utq.edu.iq}

It can observed that, at the same a/d ratio and web reinforcement, the crack width increases with increase in the replacement ratio of recycled aggregate as shown in the Figures ( 6 to 8 ). For beams with a/d ratio of (1) without stirrups, and at load $500 \mathrm{kN}$, beam with replacement ratio of $50 \%$ showed $100 \%$ wider crack compared to beam without recycle aggregate. The increase in inclined crack width was $200 \%$ for beam with 75\% replacement ratio . This behaviour is attributed to the reduction in modules of elasticity of concrete with the increase of replacement ratio of RCA.

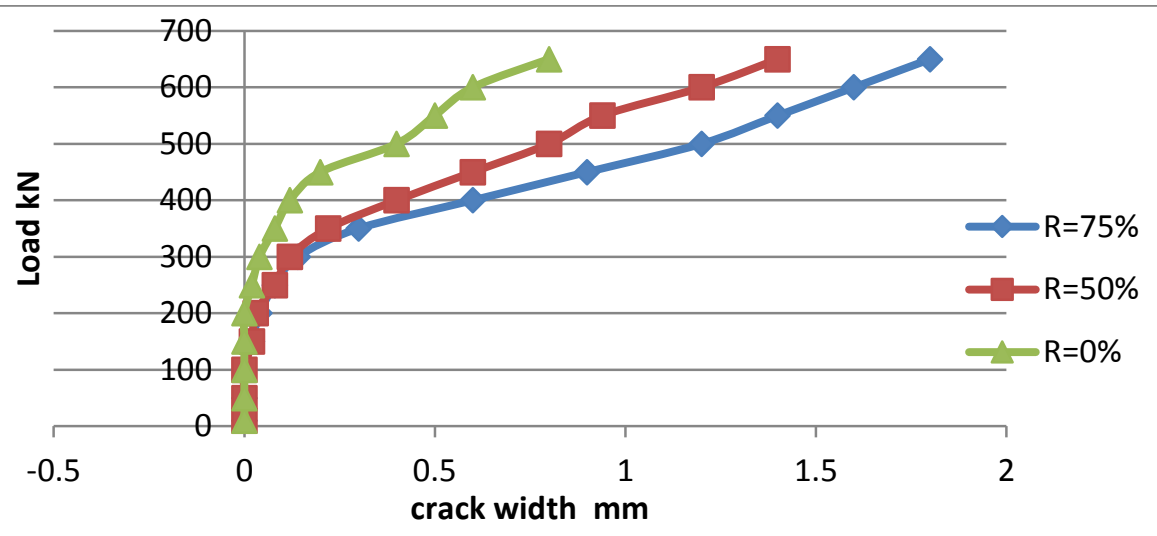

Figure (6): Load- Inclined Crack Width for T-beams without stirrups and $\mathbf{a} / \mathbf{d}=1$

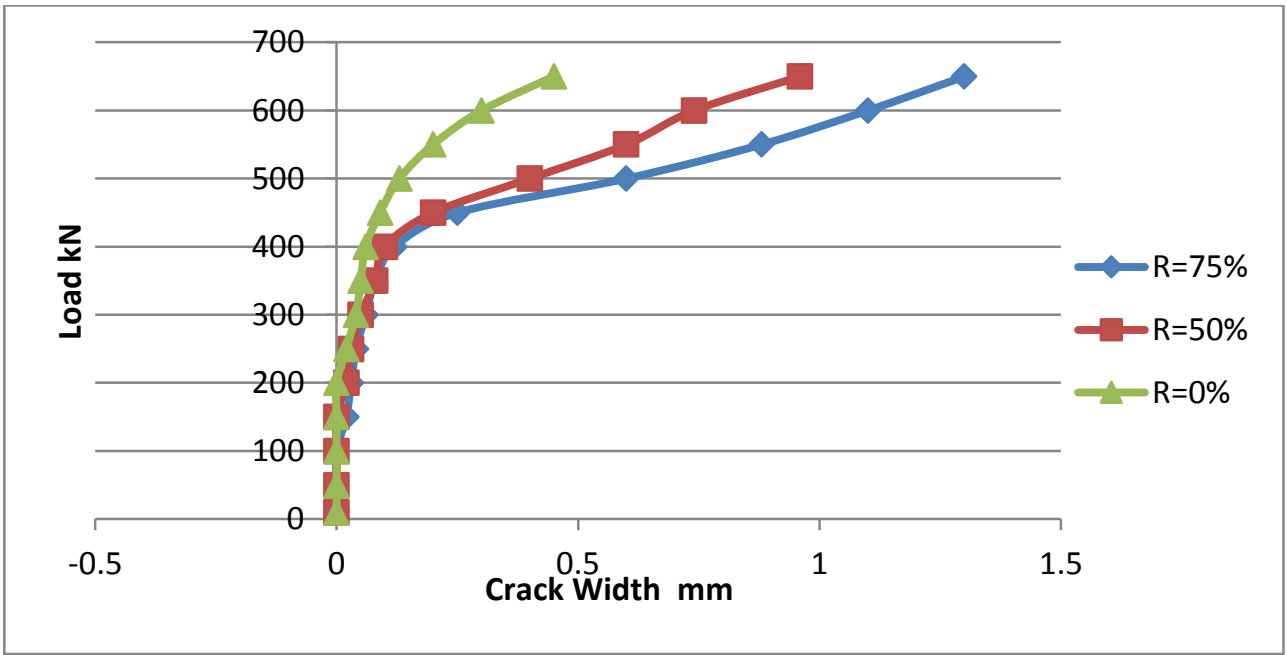


Web Site: https://jutq.utq.edu.iq/index.php/main

Email: journal@jutq.utq.edu.iq

Figure (7): Load- Inclined Crack Width for T-beams with S=50mm stirrups and $\mathbf{a} / \mathbf{d}=1$

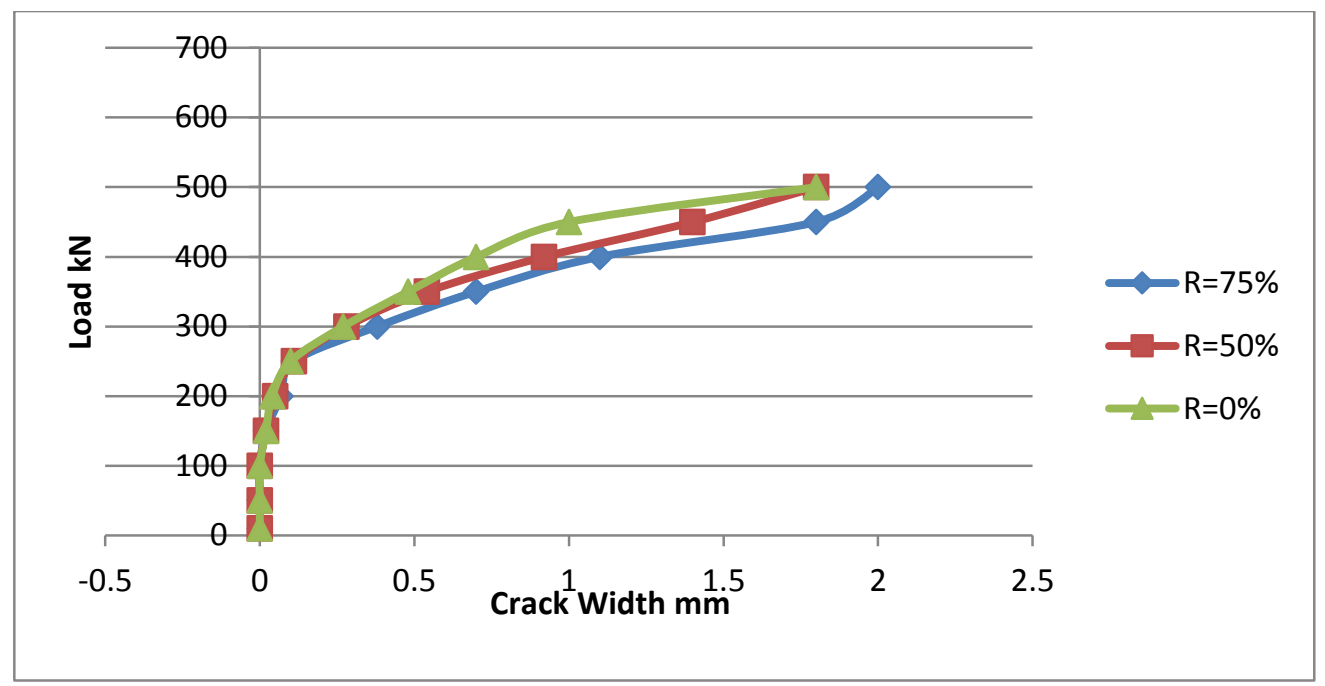

Figure (8): Load- Inclined Crack Width for T-beams with $S=100 \mathrm{~mm}$ stirrups and $\mathbf{a} / \mathbf{d}=\mathbf{2}$

\subsection{Effect of Web Reinforcement}

\subsubsection{First Cracking and Ultimate Load}

From Tables $(8,9$ and 10), it can be deducted that, the presence of web reinforcement causes an increase of about $16 \%$ in cracking load. This increase seems to be independent of a/d ratio and the RCA replacement ratio. While the effectiveness of web reinforcement have a tendency to increase with increasing the a/d ratio, and this is valid for concrete with and without RCA replacement. The average increase in ultimate loads were $4.4 \%, 18.9 \%$ and $28.4 \%$ for a/d ratio of 1,2 and 3 respectively. This behaviour results from the fact that as the a/d ratio increases the inclination of the diagonal crack will be reduced so more stirrups will be crossed by the crack.

\subsubsection{Deflections and inclined crack width}

Figures (9 and 10) present a comparison between deflection of SCC Tbeams for different values of web reinforcement (without stirrups, at $100 \mathrm{~mm}$ and at $50 \mathrm{~mm}$ ). It can be observed that, T-beams with stirrups 


\section{University of Thi-Qar Journal Vol.14 No.1 Mar 2019 \\ Web Site: https://jutq.utq.edu.iq/index.php/main}

Email: journal@jutq.utq.edu.iq

exhibited slightly lower deflection. As an example, at the load $500 \mathrm{kN}$, and for beam with a/d ratio of (1) and with RCA ratio 50\%, beam with stirrups at $100 \mathrm{~mm}$ showed (22\%) lower deflection compared to beam without stirrups while this decrease in deflection became (33\%) for beam with stirrups at $50 \mathrm{~mm}$.

Figures (11 and 12) present a comparison between crack width of SCC T-beams for different values of web reinforcement (without stirrups, at $100 \mathrm{~mm}$ and at $50 \mathrm{~mm}$ ). It can be observed that, T-beams without web reinforcement showed higher crack width. As an example, at the load $\varepsilon 00 \mathrm{kN}$, and for beam with a/d ratio of (1) and with RCA ratio $50 \%$, beam with stirrups at $100 \mathrm{~mm}$ showed (30\%) lower crack width compared to beam without stirrups while this decrease in crack width became $(75 \%)$ for beam with stirrups at $50 \mathrm{~mm}$.

The addition of stirrups did cause an increase in the stiffness of the beam system as compared to the beam without stirrups.

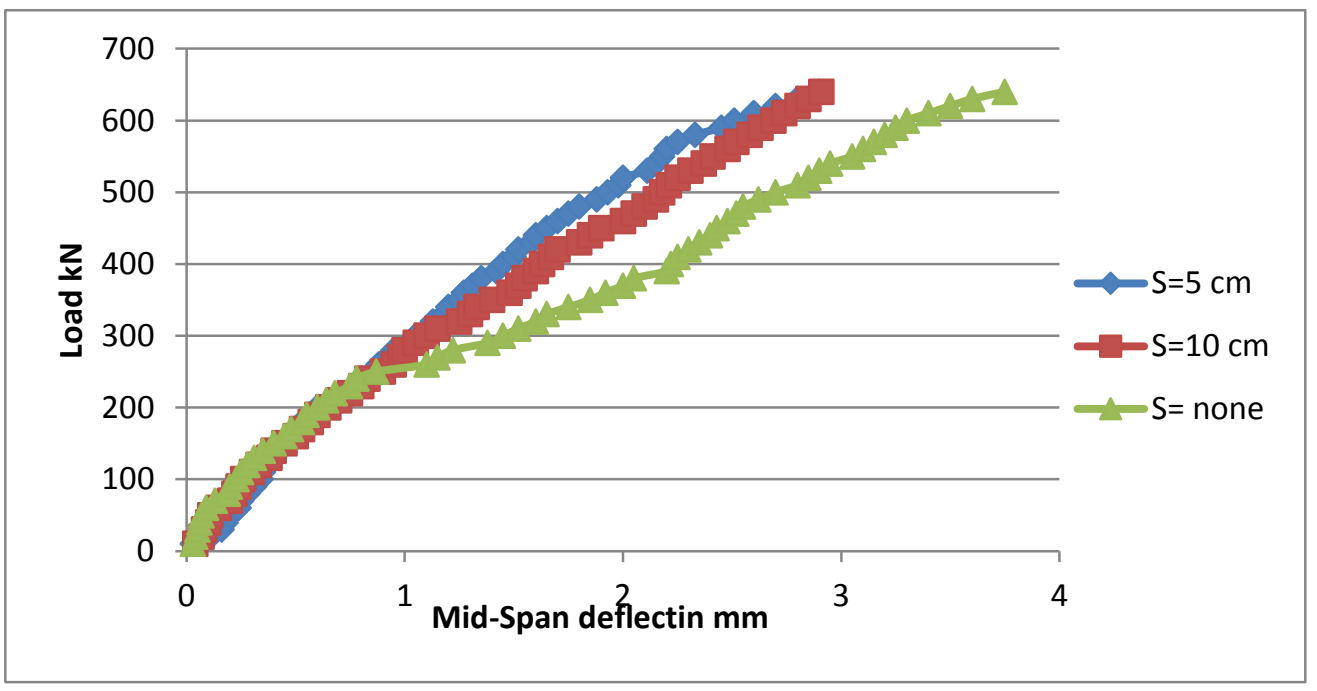

Figure (9): Experimental load versus mid- span deflection curve for T-beams with $\mathrm{a} / \mathrm{d}=1$ and $\mathrm{R}=0 \%$ 
University of Thi-Qar Journal Vol.14 No.1 Mar 2019

Web Site: https://jutq.utq.edu.iq/index.php/main

Email: journal@jutq.utq.edu.iq

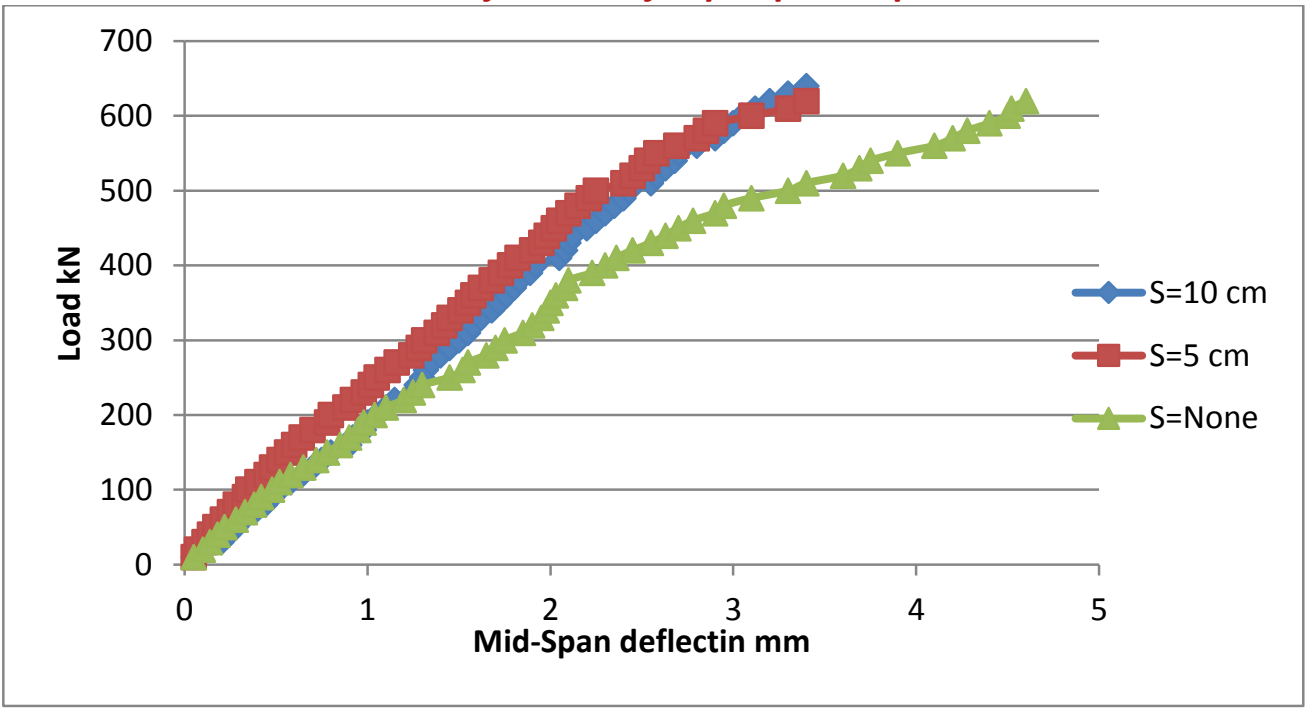

Figure (10): Experimental load versus mid- span deflection curve for T-beams with $\mathrm{a} / \mathrm{d}=\mathbf{1}$ and $\mathrm{R}=\mathbf{5 0 \%}$

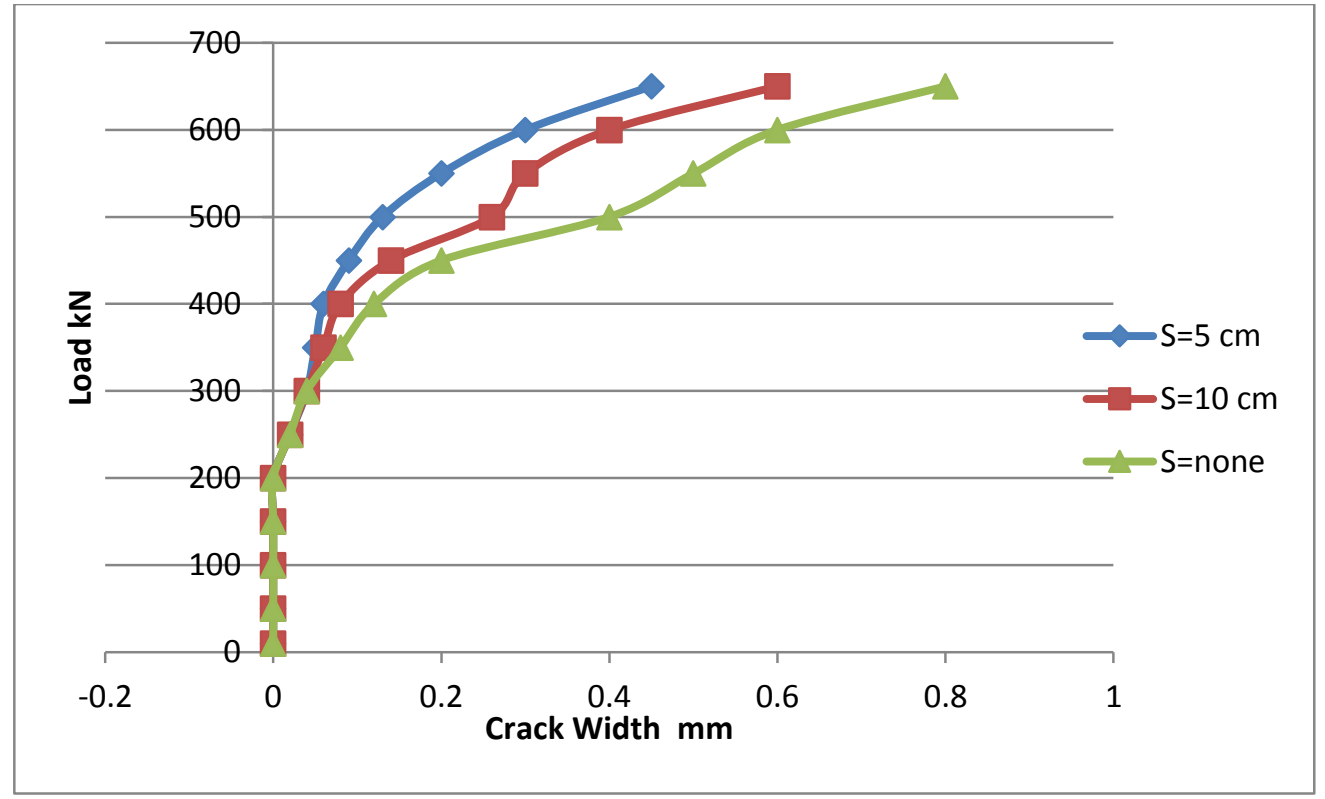

Figure (11): Load- Inclined Crack Width for T-beams with $\mathbf{a} / \mathbf{d}=1$ and $\mathbf{R}=\mathbf{0 \%}$ 
Web Site: https://jutq.utq.edu.iq/index.php/main

Email: journal@jutq.utq.edu.iq

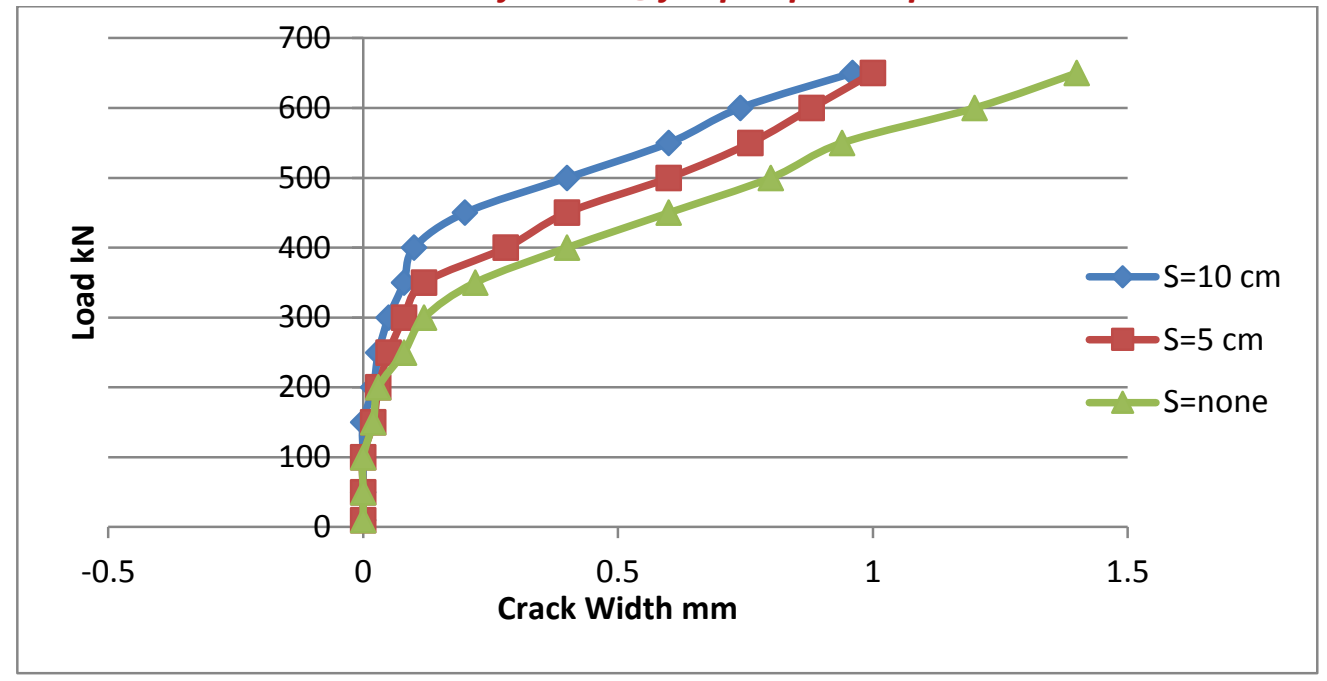

Figure (12): Load- Inclined Crack Width for T-beams with $\mathrm{a} / \mathrm{d}=1$ and $\mathbf{R}=\mathbf{5 0 \%}$

\section{Conclusion}

1- The use of recycled concrete aggregate (RCA) as a partial replacement of coarse aggregate have inversely affected the fresh properties of the self-compacting concrete but the resulting concrete remain within the limits specified for SCC.

2- Hardened concrete tests showed that self-compacted concrete with RCA replacement ratio of $50 \%$ have $12.8 \%$ lower compressive strength, $13.3 \%$ lower splitting tensile strength and $7.3 \%$ lower modulus of elasticity compared to SCC without RCA. For RCA replacement ratio of $75 \%$, the reduction become $27.5 \%, 21.2 \%$ and $17.8 \%$ respectively.

3 - For beams with a/d ratio of (1,2 and 3) and with variable stirrups (without stirrups, at $100 \mathrm{~mm}$ and at $50 \mathrm{~mm}$ ), when increasing the RCA replacement ratio to $50 \%$, the first cracking load and the ultimate load reduced by average $30 \%$ and $6 \%$ respectively. When the RCA replacement ratio was $75 \%$, the first cracking load and the ultimate load reduced $31.6 \%$ and $9.4 \%$ respectively.

4. T-beams with the higher replacement ratio of RCA exhibited slightly higher deflection. 


\section{University of Thi-Qar Journal Vol.14 No.1 Mar 2019 \\ Web Site: https://jutq.utq.edu.iq/index.php/main \\ Email: journal@jutq.utq.edu.iq}

5. At the same a/d ratio and web reinforcement, the crack width increases with increase in the replacement ratio of recycled aggregate.

6. The first cracking load and the ultimate load decreased with the increase of $(\mathrm{a} / \mathrm{d})$ ratio

7. At the same RCA ratio and web reinforcement, the crack width increases with increase in the $\mathrm{a} / \mathrm{d}$ ratio of $\mathrm{T}$-beams.

8. The presence of web reinforcement causes an increase of about $16 \%$ in cracking load. This increase seems to be independent of a/d ratio and the RCA replacement ratio. The average increase in ultimate loads were $4.4 \%, 18.9 \%$ and $28.4 \%$ for a/d ratio of 1,2 and 3 respectively.

9. T-beams without web reinforcement showed higher crack width .

\section{References}

1. Tang W., Ryan P. and Cui H., (2014), "Properties of Self-Compacting Concrete with Recycle Concrete Aggregate", Hindawi Publishing Corporation, Advances in Materials Science and Engineering, Volume 2016, Article ID 2761294, 11 pages.

2. Tviksta, L.G., "Guideline for SCC", Brite EuRam, Task 9 End Product, (2000), pp. 3-11.

3. Erkmen, B., Shield, C.K. and French, C. E., "Self-compacting Concrete (SCC) for Prestressed Bridge Girders" Final Report. Minnesota Department of Transportation. October 2008.

4. Nelson S. C. "High-Strength Structural Concrete with Recycled Aggregates", B.SC. Thesis, Faculty of Engineering and Surveying, University of Southern Queensland, Nov., 2004.

5. Iraqi Standards No.5/1984, "Ordinary Portland cement", Ministry of Housing and Construction, Baghdad,( 2004).

6. Standard Specification for Chemical Admixtures for Concrete. ASTMC494-05, American Society for Testing and Material, (2005).

7. ASTM A615/A615M-04b, "Standard Specification for Deformed and Plain Carbon Steel Bars for Concrete Reinforcement", (2004), PP. 1-6.

8. Jin, J., "Properties of Mortar for Self-compacting Concrete" Ph.D. Thesis, Department of Civil and Environmental Engineering, University College London, University of London, Jan. 2002, 398pp. 